\title{
SIMULATION ANALYSIS ON THE STRENGTH AND ACOUSTIC EMISSION CHARACTERISTICS OF JOINTED ROCK MASS
}

\author{
Zhi-jie Wen, Xiao Wang, Qing-hai Li, Guan Lin, Shao-jie Chen, Yu-jing Jiang
}

Original scientific paper

To analyse the influence of joint angle, number and spacing on the strength and acoustic emission (AE) characteristics of rock mass, the uniaxial compression model of rock specimens was established using the micro particle flow PFC2D software platform. The intact rock parameters were determined via trial and error, joints with different angles, numbers and spacing were prefabricated in the model, and a compression test was performed using the displacement control method. The compressive strength, elastic modulus, and AE time characteristics of the rock specimens increased, decreased, and then increased again along with increasing joint angle. The $\mathrm{AE}$ characteristics at joint angles $0^{\circ}, 15^{\circ}, 30^{\circ}$ and $90^{\circ}$ were consistent with those of the intact rock specimens, while the $45^{\circ} \div 75^{\circ}$ joint angle showed relatively discrete $\mathrm{AE}$ characteristics. A larger number of joints corresponded to lower uniaxial compressive strength, elastic modulus, and AE intensity. However, the time and strain range of the obvious AE were not significant. The compressive strength and $\mathrm{AE}$ signal intensity of the rock specimens increased along with joint spacing, but the AE triggering time did not show obvious changes. Uniaxial compression tests were performed via numerical simulation to avoid the non-homogeneous and discrete effects from the indoor test and to reflect accurately the influence of joint angle, number, and spacing on the strength and AE characteristics of rock mass. The results can help in generating reliable criteria for predicting the instability of engineering rock mass.

Keywords: acoustic emission; intensity; joint angle; joint number; joint spacing; jointed rock mass

Simulacijska analiza čvrstoće i karakteristika akustičke emisije raspucale stijenske mase

Izvorni znanstveni članak

Kako bi se analizirao utjecaj kuta, broja i raspona raspukline na čvrstoću i karakteristike akustičke emisije (AE) stijenske mase, postavljen je jednoosni kompresijski model uzoraka stijene uz primjenu PFC2D računalne platforme za protok mikro čestica. Metodom pokusa i pogreške određeni su originalni parametri stijene, u modelu su unaprijed izvedene raspukline različitih kutova, brojeva i razmaka, te je provedeno ispitivanje na pritisak metodom praćenja pomaka. Tlačna čvrstoća, modul elastičnosti i vremenske karakteristike AE uzoraka stijene su se povećali, smanjili te ponovo povećali kako se povećavao kut raspukline. Karakteristike AE kod raspukline kutova $0^{\circ}, 15^{\circ}, 30^{\circ}$ i $90^{\circ}$ bile su u skladu s onima kod originalnih uzoraka stijene, dok su se kod kuta raspukline od $45^{\circ} \div 75^{\circ}$ pojavile relativno diskretne karakteristike AE. Veći broj raspuklina podudarao se u nižoj jednoosnoj tlačnoj čvrstoći, modulu elastičnosti i intenzitetu AE. Međutim, nije došlo do značajne promjene u vremenu i veličini deformacije. Tlačna čvrstoća i intenzitet signala AE uzoraka stijene porasli su s povećanjem razmaka raspukline, ali se to nije pokazalo na pokazivaču vremena AE. Jednoosna ispitivanja kompresije provedena su numeričkom simulacijom kako bi se izbjegli nehomogeni i diskretni učinci ispitivanja u zatvorenom prostoru i točno odredio utjecaj kuta, broja i razmaka raspukline na čvrstoću i karakteristike AE stijenske mase. Rezultati mogu pomoći kod određivanja odgovarajućih kriterija za predviđanje nestabilnosti stijenske mase.

Ključne riječi: akustička emisija; broj raspukline; intenzitet; kut raspukline; raspucala stijenska masa; razmak raspukline

\section{Introduction}

Natural rock masses usually contain a large number of joints and cracks on a discontinuous structural surface, which results in the high complexity, heterogeneity, discontinuity, and anisotropy of these materials. The instability failure of rock and soil engineering, coal mine roof fall, and coal-gas burst are not controlled by the strength of intact rock masses, but by the degree of development of the joints and fissures in the rock masses. Rock deformation and failure are accompanied by acoustic emission, which can monitor and predict the stability and rock burst of mines in a continuous, real-time, and effective manner. Although AE technology has witnessed significant progress in its theory and application, predicting rock mass instability remains difficult because of the complexity and failure mode of rock materials. Therefore, the strength and $\mathrm{AE}$ characteristics of jointed rock mass must be investigated further to understand their failure mechanism and to devise a reasonable criteria for predicting rock failure based on AE parameters.

\section{State of the art}

Many experiments have been performed to examine the strength and failure mode of jointed rock masses

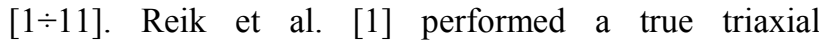
compression experiment that focused on the influence of the orientation and intermediate principal stress of joints on the strength of rock mass. Intermediate principal stress slightly affected the strength of rock mass when such stress occurred parallel to the joint. Laijtai [4] performed the direct shear test to intermittent jointed rock mass, proposed composite damage theory, and found that body strength was a product of the rock block and joint contribution. Niu et al. [6] used the numerical method to examine the sensitivity of jointed rock mass to various factors. The peak strength of jointed rock mass was controlled by joint geometry parameters, and the residual strength depended on the mechanical properties of the joints. Shear failure was the main failure mode of jointed rock mass, while joint density was the most important factor that affects rock strength. Chen et al. [9] examined how the status and orientation of joint group affected the strength, elastic modulus, and stress-strain curve of jointed rock mass, and found that the ductility of the stress-strain curve and the peak strength and elastic modulus of the rock were gradually reduced along with increasing joint connectivity. Liu et al. [11] studied how joint angle, length to diameter ratio, joint filling thickness, and types of joints were related to the strength and failure mode of jointed rock mass. They found that the failure mode and peak strength of jointed rock mass were closely 
related to the structural form of joints. The failure mode of the continuous jointed rock mass would run through or along with the joint surfaces. However, the afore mentioned studies failed to eliminate the influence of the heterogeneity and dispersion of the test piece, which cannot reflect the influence of specific rock parameters on the strength and $\mathrm{AE}$ characteristics of jointed rock mass.

The AE characteristics literature has generally examined the relationship among stress, strain, and $\mathrm{AE}$ parameters under the compression, tensioning, and shearing processes before the rock reaches its peak strength $[12 \div 15]$. However, the damage and rupture of jointed rock masses were rarely discussed. To this end, the uniaxial compression model of rock specimens was built using PFC2D, and the effects of joint angle, joint number, and joint spacing on the strength and $\mathrm{AE}$ characteristics of these specimens were investigated.

The rest of this paper is organized as follows. Section 3 establishes the uniaxial compression model of jointed rock mass using the micro particle flow PFC2D software platform. Section 4 analyses the strength and acoustic emission characteristics of jointed rock mass with different joint angles, numbers, and spacing. Section 5 summarizes the paper.

\section{Methodology}

The effects of different joint angles, numbers, and spacing on the strength and $\mathrm{AE}$ characteristics of rock mass are investigated using particles flow theory, numerical model parameter calibration, the uniaxial compression numerical model of jointed rock mass, and the AE monitoring method based on particle flow theory.

\subsection{Particle flow code}

Using the discrete element method, Cundall and Strack [16] established particle flow theory to offer a microscopic analysis of the damage evolution mechanism and failure process of rock materials. Particle flow code (PFC) presents two bond models, namely, contact bond and parallel bond, to simulate the damage of the particle bond [17]. Contact bond refers to the bond between the particle points, and the force can only be generated when the particle demonstrates relative displacement. Given that the moment of force cannot be transmitted, the contact bond applies to granular materials (e.g., soil mass) Parallel bond refers to the plane-to-plane bond between particles. Given that the moment of force can be transmitted, the parallel bond applies to compact materials, such as rocks. The uniaxial compression model of rock specimens was built using the parallel bond.

\subsection{Physico-mechanical parameters of rock specimens}

Particle flow theory represents the macroscopic physico-mechanical properties of rocks as their microscopic physico-mechanical properties. However, the microscopic parameters of rocks do not directly correspond to their macroscopic parameters. The microscopic parameters were checked and corrected prior to the numerical simulation of the uniaxial compression model. During this process, a large number of numerical simulation tests were performed as either laboratory or insitu field tests under similar conditions. The numerical simulation results were compared with the laboratory or in-situ field test results, and the microscopic parameters were repeatedly adjusted via trial and error [18].

\subsubsection{Determining the initial value of the physico- mechanical parameters}

The meso-mechanical parameters of the micro particle flow model mainly include the contact modulus of the particles $E_{c}$, particle normal stiffness and tangential stiffness ratio $k_{n} / k_{s}$, friction coefficient $f$, parallel bond radius multiplier $\lambda$, bond modulus $\bar{E}_{c}$, ratio of the normal stiffness and tangential stiffness of bond $\bar{k}_{n} / \bar{k}_{s}$, and normal and tangential bond strengths $\bar{\sigma}_{c}$ and $\bar{\tau}_{c}$.

The macro-mechanical parameters (including elastic modulus $E$, Poisson's ratio $v$, compressive strength value $\sigma_{c}$, and shear strengths $c$ and $\varphi$ ) of the materials were determined in the indoor test. The preliminary value of particle contact modulus $E_{c}$ and parallel bond modulus $\bar{E}_{c}$ was decided by analysing the macroscopic mechanical parameters.

The initial particle stiffness value is computed as follows:

$k_{n}=2 t E_{c},(t=1)$,

$k_{s}=\frac{k_{n}}{\left(k_{n} / k_{s}\right)}$,

$\bar{R}=\frac{R^{[A]}+R^{[B]}}{2}$.

where $\bar{R}$ is the average radius of all model particles, and $R^{[A]}$ and $R^{[B]}$ are the radiuses of two contact particles.

The initial normal and tangential stiffness of the parallel bonding is computed as follows:

$$
\begin{aligned}
& \bar{k}_{n}=\frac{\bar{E}_{c}}{R^{[A]}+R^{[B]}}, \\
& \bar{k}_{s}=\frac{\bar{k}_{n}}{\left(\bar{k}_{n} / \bar{k}_{s}\right)} .
\end{aligned}
$$

\subsubsection{Determining the meso-mechanical properties of rock}

Using the mechanical parameters that were generated from the triaxial compression test of granite specimens collected from the underground-water-sealed oil storage caverns in Huangdao, the microscopic mechanical parameters of the rock specimens were determined via trial and error as shown in Tab. 1 [19]. After correction, the macroscopic mechanical parameters of the specimens as obtained from the numerical simulation under the confining pressure of $6 \mathrm{MPa}$ agreed well with the macroscopic mechanical parameters of real granite that were obtained under the same confining pressure. The specimens under these two conditions obtained an elastic modulus, Poisson's ratio, and compressive strength of 
$28,7 \mathrm{GPa}(28,4 \mathrm{GPa}), 0,2300(0,2285)$, and $130,5 \mathrm{MPa}$ $(132,8 \mathrm{MPa})$. Fig. 1 shows the failure mode of the specimens, and the results agree well with those from the laboratory test.

Table 1 Physico-mechanical parameters of granite

\begin{tabular}{|c|c|c|c|}
\hline Parameter & Value & Parameter & Value \\
\hline $\begin{array}{l}\text { Minimum particle } \\
\text { size }(\mathrm{mm})\end{array}$ & 0,3 & $\begin{array}{c}\text { Normal/tangential } \\
\text { stiffness }\end{array}$ & 3,0 \\
\hline Particle size ratio & 1,66 & $\begin{array}{l}\text { Coefficient of } \\
\text { friction }\end{array}$ & 0,8 \\
\hline Density $\left(\mathrm{kg} / \mathrm{m}^{3}\right)$ & 2800 & \multirow{2}{*}{$\begin{array}{c}\text { Parallel bond } \\
\text { Normal stiffness } \\
(\mathrm{MPa})\end{array}$} & \multirow[b]{2}{*}{$88 \pm 10$} \\
\hline $\begin{array}{l}\text { Contact modulus of } \\
\text { the particle }(\mathrm{GPa})\end{array}$ & 5,0 & & \\
\hline $\begin{array}{l}\text { Deformation of } \\
\text { parallel bond } \\
\text { Modulus (GPa) }\end{array}$ & 43,0 & $\begin{array}{c}\text { Parallel bond } \\
\text { Tangential } \\
\text { stiffness (MPa) }\end{array}$ & $160 \pm 10$ \\
\hline
\end{tabular}

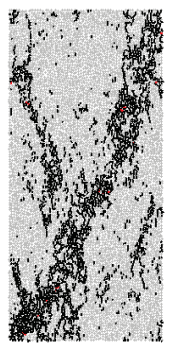

(a) PFC

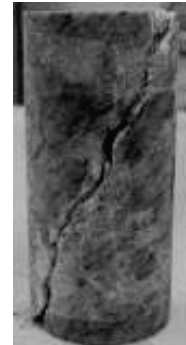

(b) Granite
Figure 1 Failure modes of granite in compression at a confining stress of $6 \mathrm{MPa}$

\subsection{Uniaxial compression model of jointed rock mass}

PFC characterizes the joint element by reducing the particle strength [20]. To analyse the influence of joint angle, number, and spacing on the strength and $\mathrm{AE}$ characteristics of rock mass, three groups of jointed rock mass were established based on the abovementioned parameters.

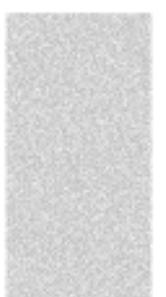

(a) No joint

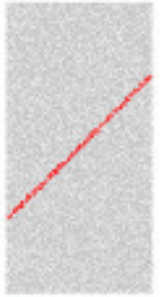

(e) $45^{\circ}$

Figure 2 Rock $60^{\circ}$.

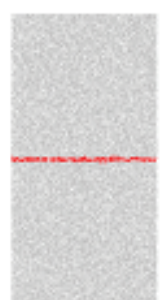

(b) $0^{\circ}$

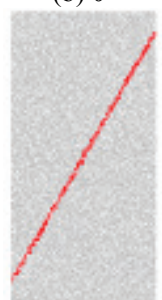

(f) $60^{\circ}$

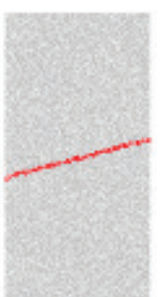

(c) $15^{\circ}$

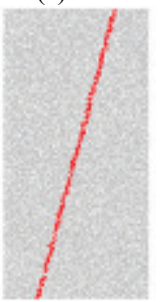

(g) $75^{\circ}$

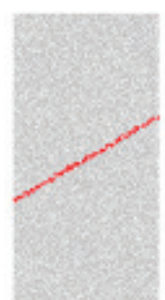

(d) $30^{\circ}$

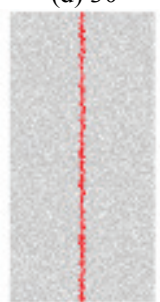

(h) $90^{\circ}$
Eight joint angles (e.g., no joint, $0^{\circ}, 15^{\circ}, 30^{\circ}, 45^{\circ}$ $60^{\circ}, 75^{\circ}$ and $90^{\circ}$, Fig. 2), three joint numbers (e.g., 1, 2, and 3, Fig. 3), and three joint spacing (e.g., $10 \mathrm{~mm}, 15$ $\mathrm{mm}$, and $20 \mathrm{~mm}$, Fig. 4) were considered. The uniaxial compression model of rock masses with persistent joints was established under these conditions, with the strength of the parallel bond set to 0 . Loading was performed by moving the wall on the top at a rate of $0,01 \mathrm{~mm} / \mathrm{s}$. The wall was extended accordingly to prevent the particles from escaping.

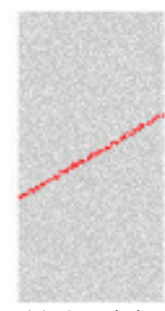

(a) One join Figure 3 Rock

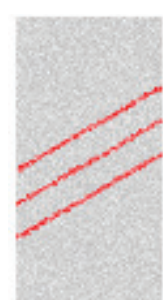

(a) $10 \mathrm{~mm}$

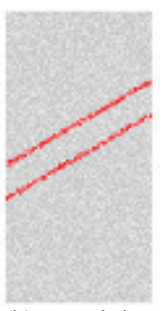

(b) Two joints

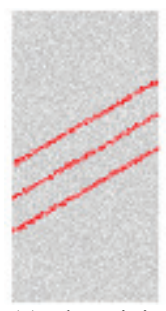

(c) Three joints Figure 4 Rock specimens with different joint spacing

\subsection{AE simulation by PFC}

During the loading process of the particle bond model, the bond fractures when the intensity of the transmitted stress between the particles exceeds the bonding strength between the particles, thereby producing micro cracks on the rock specimen [21]. Propagating these micro cracks rapidly releases damage energy as acoustic waves, which represent the AE phenomenon. Therefore, when the compression of the rock specimen is simulated using PFC, the FISH-language-based program can monitor the number of fractured parallel bonds at each moment. In this way, the AE characteristics can be analysed.

\section{Result analysis and discussion \\ 4.1 Joint angle \\ 4.1.1 Effect of joint angle on the compressive strength of rock specimens}

Figs. 5 and 6 show the influence of joint angle $\alpha$ on the compressive strength of the rock specimens. The compressive strength initially decreases and then increases along with increasing joint angle $\alpha$. The curve shows a typical V-shape. The joint angle $\alpha$ only slightly influences compressive strength when the joint angle is lower than $45^{\circ}$ or equal to $90^{\circ}$. However, such influence increases at a $45^{\circ} \div 75^{\circ}$ joint angle, and peaks at a $60^{\circ}$ joint angle (the uniaxial compressive strength at a $60^{\circ}$ joint angle accounts for only $9,68 \%$ of the compressive strength of the intact rock specimen). Fig. 5 shows that the elastic modulus varies along with joint angle, that is, the elastic modulus initially decreases and then increases with increasing joint angle. The curve characteristics at a $75^{\circ}$ joint angle suggest that the stress slightly rebounds after a decrease, and this variation persists along with changing strain. Such observation can be attributed to the failure of the top of the joint during the joint opening process (Fig. 7g) and the fragmented rock pieces blocking 
the joint space. The destruction of fragments expands the contact area of the wall when using FISH language to monitor the stress of the model based on the contact mean stress of the wall. Fig. 7 shows two major failure modes under different joint angles, namely, tensile failure running through the joint plane and shear failure running along the joint plane. Tensile failure occurs at $0^{\circ}, 15^{\circ}, 30^{\circ}$ and $90^{\circ}$ joint angles, while shear failure occurs at $45^{\circ}, 60^{\circ}$ and $75^{\circ}$ joint angles. The damage at $0^{\circ}, 15^{\circ}$, and $90^{\circ}$ joint angles is concentrated in the upper part of the joint, while that at $30^{\circ}$ is concentrated in the lower part of the joint. The rock specimens face less severe damage at the $45^{\circ} \div$ $75^{\circ}$ joint angle, and do not face any damage except in the joint area at the $60^{\circ}$ joint angle.

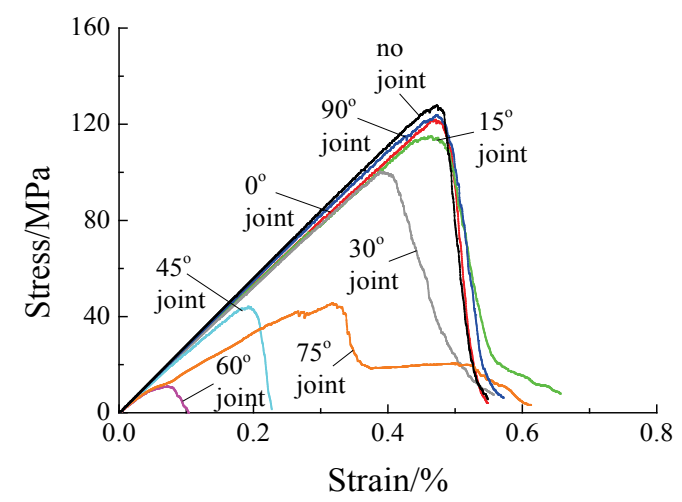

Figure 5 Stress-strain curves of granite with different joint angles

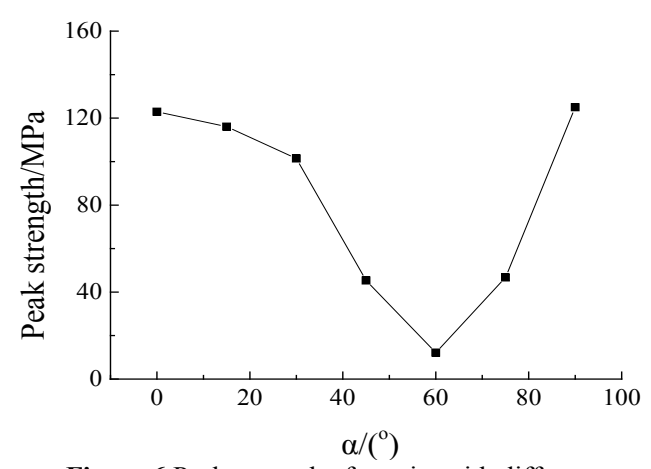

Figure 6 Peak strength of granite with different joint angles

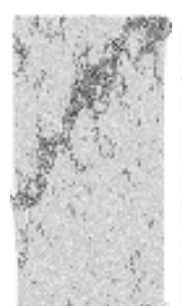

(a) No joint

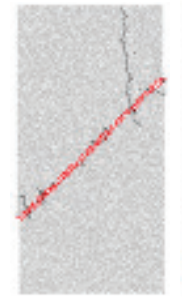

(e) $45^{\circ}$

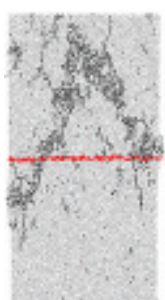

(b) $0^{\circ}$

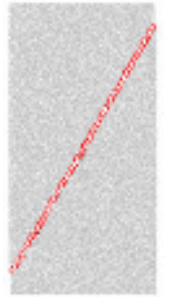

(f) $60^{\circ}$

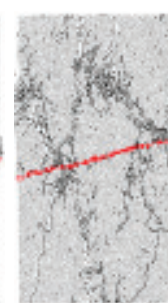

(c) $15^{\circ}$

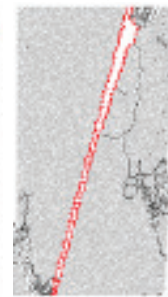

(g) $75^{\circ}$

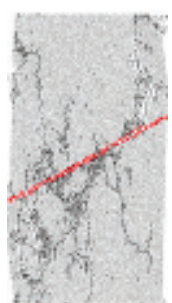

(d) $30^{\circ}$

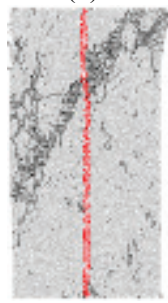

(h) $90^{\circ}$ joint angles

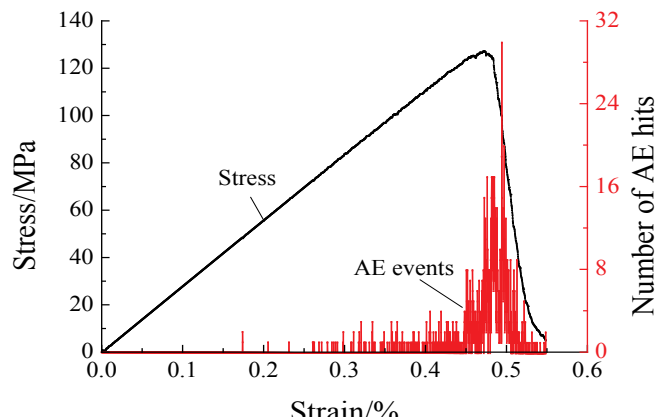

(a) No joint

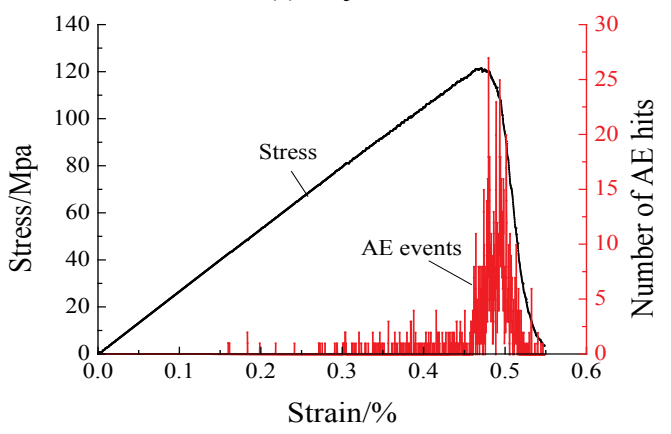

(b) $0^{\circ}$

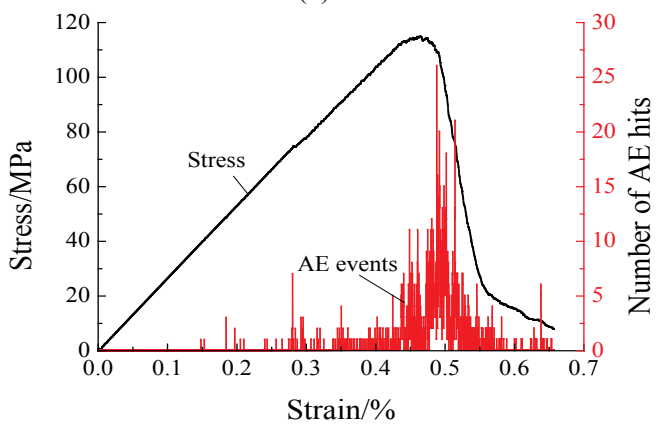

(c) $15^{\circ}$

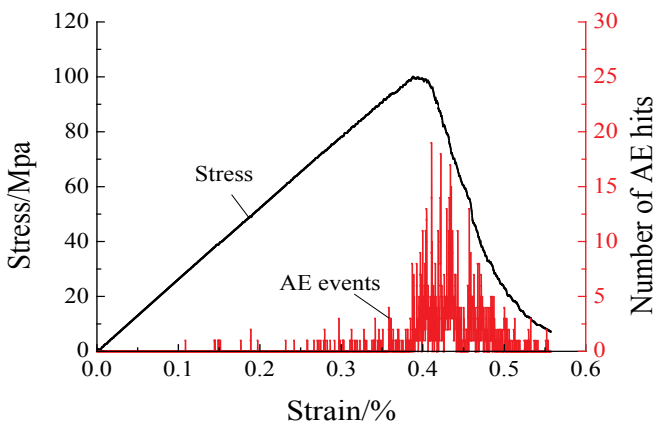

(d) $30^{\circ}$

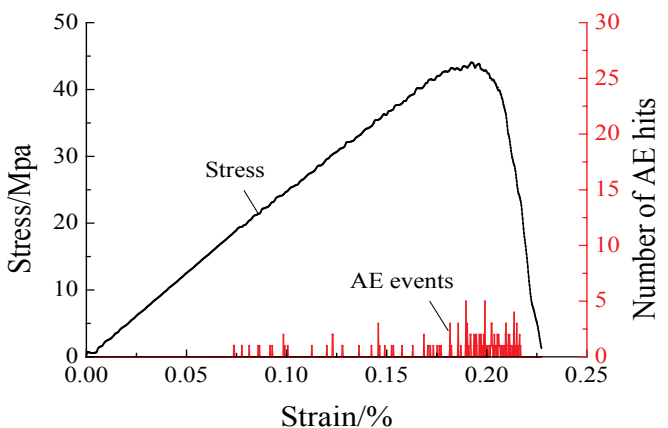

(e) $45^{\circ}$

Figure 8 AE characteristic curves of rock specimens with different joint angles 


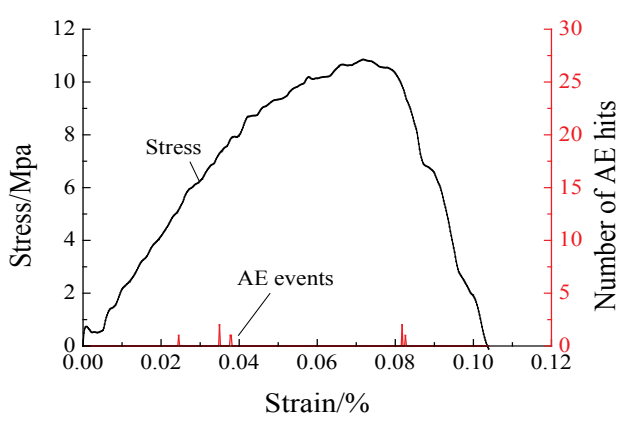

(f) $60^{\circ}$

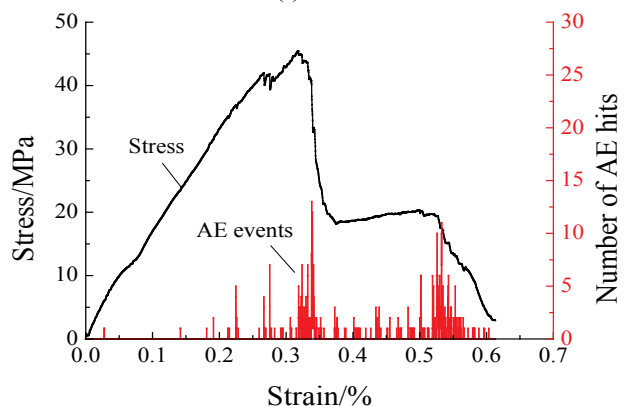

(g) $75^{\circ}$

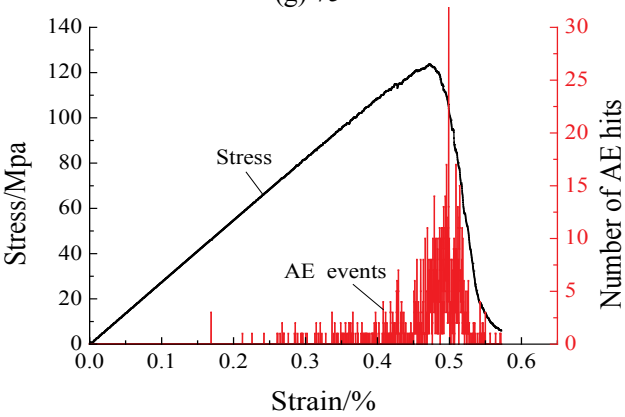

(h) $90^{\circ}$

Figure 8 AE characteristic curves of rock specimens with different joint angles (continuation)

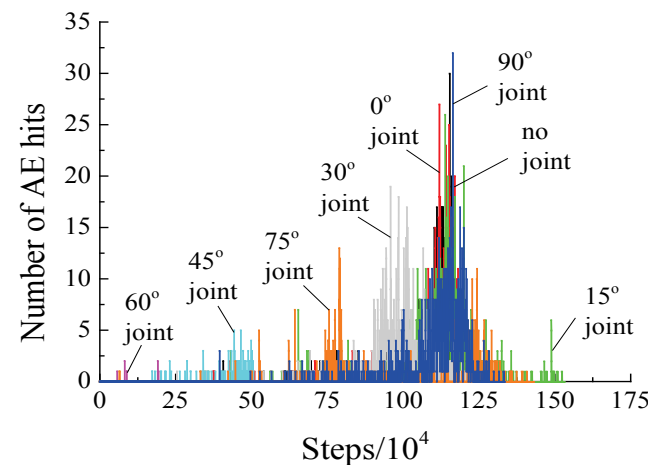

Figure 9 AE-time characteristic curves of rock specimens with different joint angles

\subsubsection{Effect of joint angle on the AE characteristics of rock specimen damage}

Fig. 8 shows that the $\mathrm{AE}$ characteristics at $0^{\circ}, 15^{\circ}$, $30^{\circ}$ and $90^{\circ}$ joint angles are consistent with those of the intact rock specimen. The impact signals change across three phases. First, the impact signals are reduced during the compaction and elastic changes of the rock specimens. Second, these signals abruptly increase in number during the hardening of the specimen. Third, these signals abruptly decrease in number during the softening of the strain. However, the AE characteristics at the $45^{\circ} \div 75^{\circ}$ joint angle are more discrete than those at other joint angles. The effect of joint angle on the AE characteristics of rock specimen damage can be summarized as follows: (1) joint angle affects the crack initiation strain. As the joint angle increases, the crack initiation strain increases, decreases, and then increases again; (2) the scope of strain corresponding to obvious AE varies along with joint angle, that is, the scope of strain is widened, narrowed, and then widened again; (3) joint angle affects the intensity of AE, which increases, decreases, and then increases again; and (4) joint angle affects the AE triggering time (Fig. 9), that is, the AE triggering time is delayed, advanced, and then delayed again. These changes agree with the effects of joint angle on the strength of the rock specimen, which also shows a V-shaped curve. No $\mathrm{AE}$ is detected at the $60^{\circ}$ joint angle, which suggests the failure of the $60^{\circ}$ joint rock and the sliding failure of the joint plane. Two $\mathrm{AE}$ peaks are detected at the $75^{\circ}$ joint angle, and the occurrence of the second peak has been explained above.

\subsection{Joint number \\ 4.2.1 Effect of joint number on the compressive strength of rock specimens}

Compression tests were performed on rock specimens with different joint numbers (e.g., 1, 2, and 3). Fig. 10 shows the stress-strain curve of these specimens, while Figure 11 shows their failure modes. The specimens with 1, 2, and 3 joints have peak strengths of 101,42 $\mathrm{MPa}$, $81,17 \mathrm{MPa}$, and $73,71 \mathrm{MPa}$, respectively. The peak strength decreases along with increasing joint number, which suggests the weakening interaction between the joints. The elastic modulus of the rock specimen also decreases along with increasing joint number. The failure is concentrated in the lower part of the rock specimen with 1 joint, in the upper part of the rock specimen with 2 joints (these joints are located near the top of the specimen), and between the joints in the rock specimen with 3 joints (these joints have obviously weakening interactions).

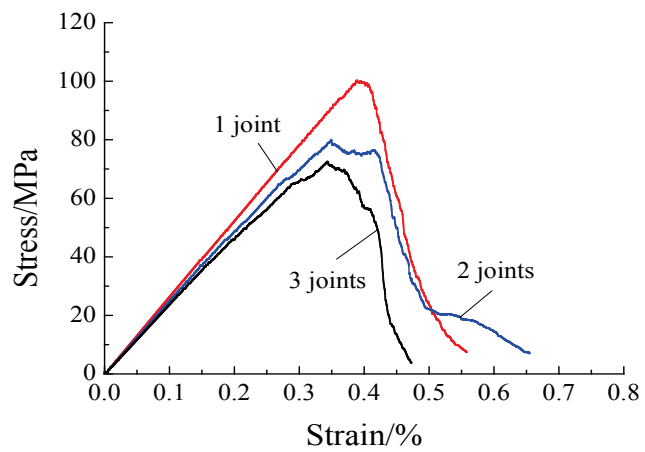

Figure 10 Stress-strain curves of rock specimens with different joint numbers

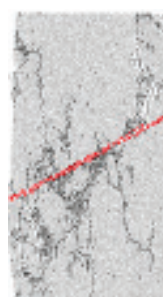

(a) 1 joint

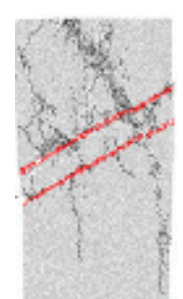

(b) 2 joints

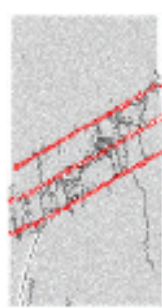

(c) 3 joints
Figure 11 Failure modes of rock specimens with different joint sets 


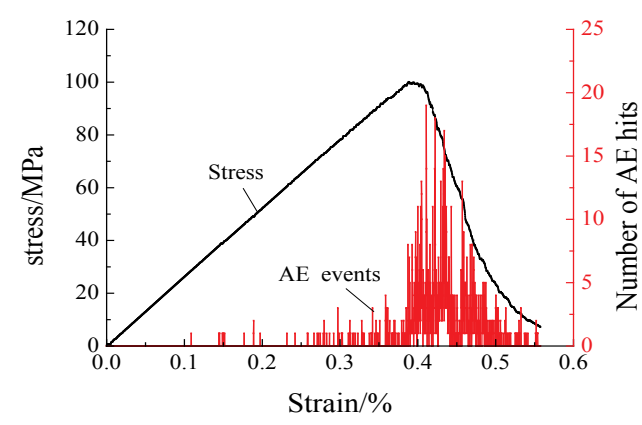

(a) 1 joint

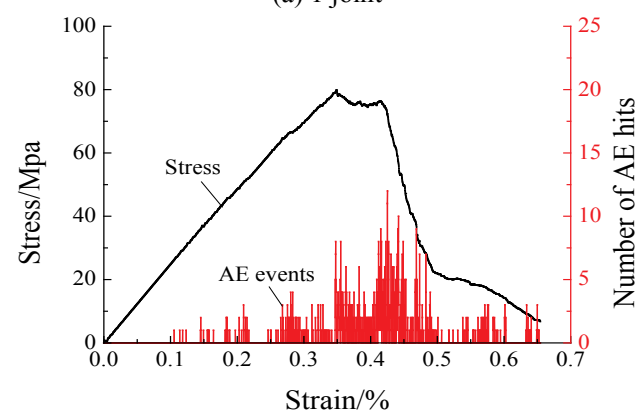

(b) 2 joints

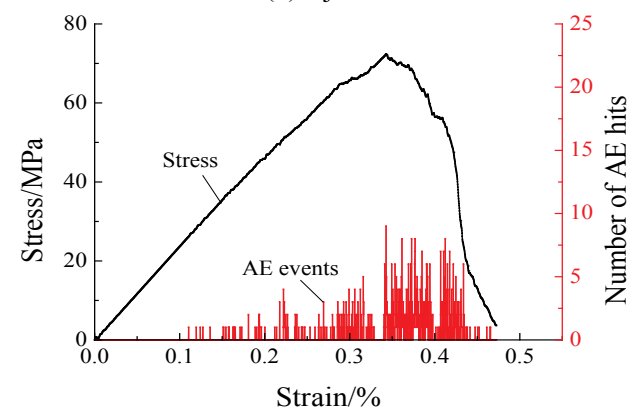

(c) 3 joints

Figure 12 AE characteristic curves of rock specimens with different joint numbers

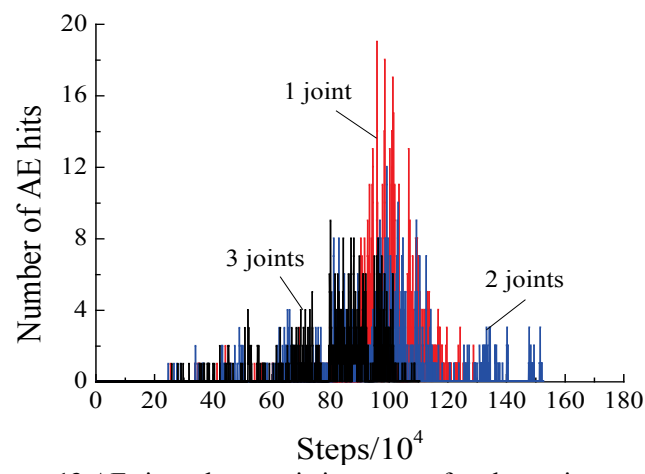

Figure 13 AE-time characteristic curves of rock specimens with different joint numbers

\subsubsection{Effect of joint number on the AE characteristics of rock specimen damage}

Fig. 12 shows the AE characteristic curves of rock specimens with different joint numbers, while Fig. 13 shows their AE characteristic-time curves. Joint number affects the AE characteristics of the specimens. The AE characteristics of the rock specimen with 1 joint undergo initial emission, increases and then gradually decreases three stages. The AE characteristics of rock specimens with 2 and 3 joints show a weakened stage of obvious emission, while the declining stage does not gradually decrease amid demonstrating large fluctuations. Although the intensity of the AE characteristics is weakened with increasing joint number, joint number only slightly affects the AE triggering time and the scope of strain that corresponds to serious $\mathrm{AE}$ characteristics.

\subsection{Joint spacing \\ 4.3.1 Effect of joint spacing on the compressive strength of rock specimens}

Compression tests were performed at the $30^{\circ}$ joint angle and at $10 \mathrm{~mm}, 15 \mathrm{~mm}$, and $20 \mathrm{~mm}$ joint spacing. Fig. 14 shows the stress-strain curves of the rock specimens with different joint spacing, while Fig. 15 shows their failure modes. The specimens with joint spacing of $10 \mathrm{~mm}, 15 \mathrm{~mm}$, and $20 \mathrm{~mm}$ have peak strengths of $73,71 \mathrm{MPa}, 81,91 \mathrm{MPa}$, and $87,66 \mathrm{MPa}$, respectively. The uniaxial compressive strength increases along with joint spacing, which suggests that closer joints demonstrate greater interactions. Joint spacing has little effect on elastic modulus of the rock specimen. Despite the peak strength increasing along with joint spacing, the scope of failure is confined within the area of joints, thereby demonstrating the "enveloping" effect of joints on the failure.

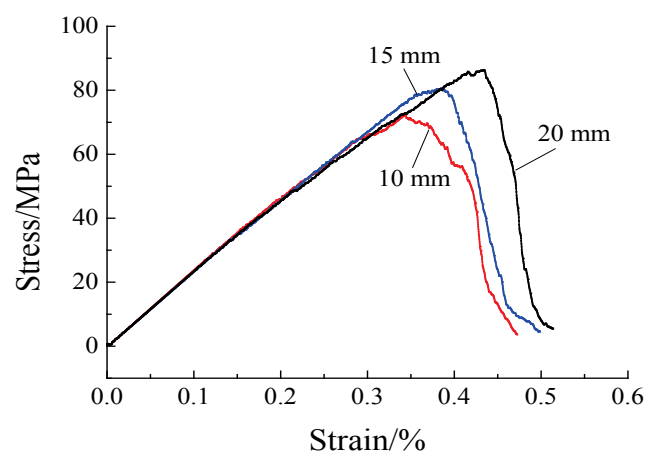

Figure 14 Stress-strain curves of rock specimens with different joint spacing

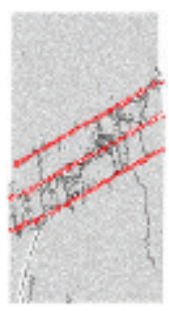

(a) $10 \mathrm{~mm}$

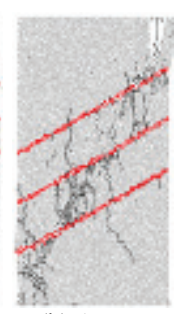

(b) $15 \mathrm{~mm}$

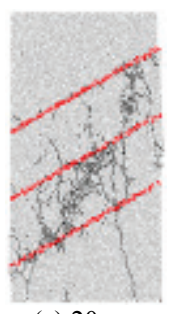

(c) $20 \mathrm{~mm}$
Figure 15 Failure modes of rock specimens with different joint spacing

\subsubsection{Effect of joint spacing on the AE characteristics of rock specimen damage}

Figs. 16 and 17 show that the influence of joint spacing on AE characteristics is mainly reflected in the AE signal intensity, which increases along with joint spacing. A larger joint spacing corresponds to a later occurrence of strong AE, but this effect is not very obvious. Joint spacing slightly affects the scope of the strain that corresponds to strong AE. 


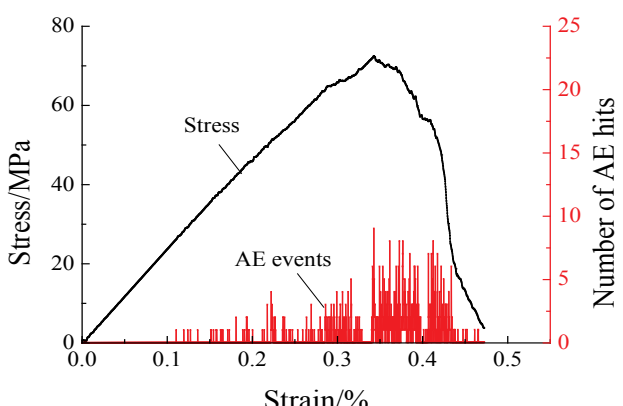

(a) $10 \mathrm{~mm}$

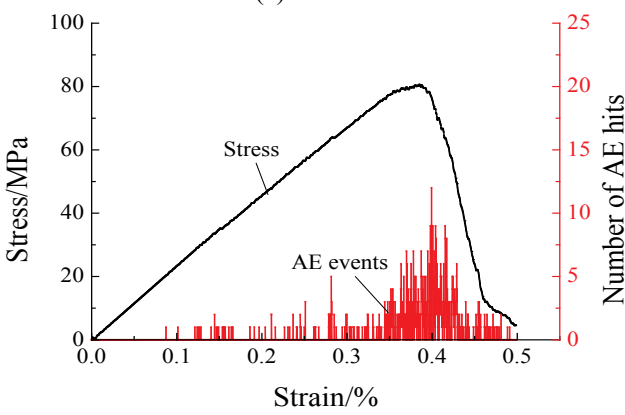

(b) $15 \mathrm{~mm}$

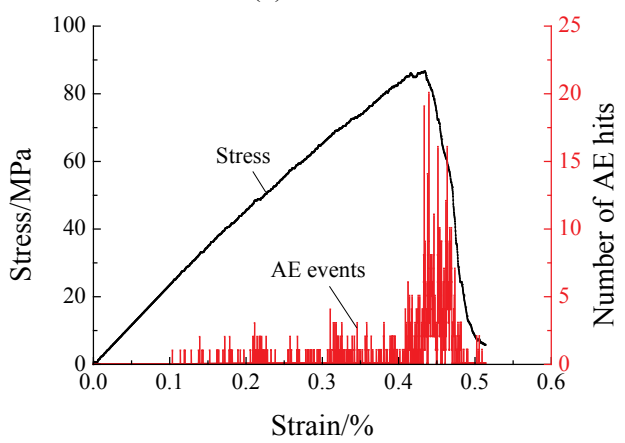

(c) $20 \mathrm{~mm}$

Figure 16 AE characteristic curves of rock specimens with different joint spacing

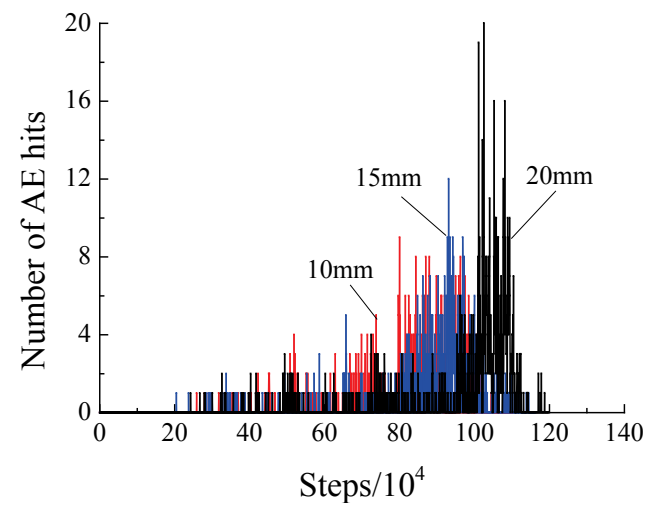

Figure 17 AE-time characteristic curves of rock specimens with different joint spacing

\section{Conclusion}

To analyse the effect of joint angle, number, and spacing on the strength and AE characteristics of rock mass, the uniaxial compression model of various jointed rock specimens was established using the particle flow software PFC2D, which can accurately reflect real rock properties and avoid the influence of rock heterogeneity and dispersion. The main research results are listed as follows:
(1) When the joint angle increases, the compressive strength, elastic modulus, and $\mathrm{AE}$ time characteristics show a typical V-trend; the $\mathrm{AE}$ characteristics at $0^{\circ}, 15^{\circ}$, $30^{\circ}$, and $90^{\circ}$ joint angles are consistent with those of the intact rock specimens, but the $45^{\circ} \div 75^{\circ}$ joint angle shows relatively discrete joint characteristics.

(2) The uniaxial compressive strength and elastic modulus of the rock specimen decrease along with joint number, while the intensity of $\mathrm{AE}$ characteristics decreases along with increasing joint number. Joint number only has a slight effect on AE triggering time and the scope of strain that corresponds to strong AE.

(3) An increase in joint spacing significantly increases the uniaxial compressive strength of the rock specimen. The scope of failure is mainly confined within the area of joints. An increase in joint spacing also enhances the intensity of AE characteristics. Large joint spacing delays the triggering time of strong AE, but this effect is not very obvious.

(4) The above results illustrate the failure mechanisms of rock mass and propose reasonable criteria for predicting rock failure based on $\mathrm{AE}$ parameters. However, the proposed model cannot represent real rock mass. In our next analysis, we will examine the strength and $\mathrm{AE}$ characteristics of real rock mass to propose criteria for predicting rock mass instability.

\section{Acknowledgement}

This work was supported by the National Natural Science Foundation of China (Nos. 51304126 and 51304235), Fok Ying Tung Education Foundation (No. 141046), China Postdoctoral Science Foundation (No. 2013M541918), Shan Dong University of Science and Technology Outstanding Young Investigator Award (No. 2014JQJH105), Shandong Province Higher Educational Science and Technology Program (No. J15LH04), State Key Laboratory of Open Funds (No. SKLGDUEK1520), Tai'shan Scholar Engineering Construction Fund of the Shandong Province of China; Tai'shan Scholar Talent Team Support Plan for Advanced \& Unique Discipline Areas, and the State Key research Development Program of China (No. 2016YFC0600708-3).

\section{References}

[1] Reik, G.; Zacas, M. Strength and deformation characteristics of jointed media in true triaxial compression. // International Journal of Rock Mechanics \& Mining Sciences \& Geomechanics Abstracts. 15, 6(1978), pp. 295303. DOI: 10.1016/0148-9062(78)91470-5

[2] Singh, M.; Rao, K. S.; Ramamurthy, T. Strength and Deformational Behaviour of a Jointed Rock Mass. // Rock Mechanics \& Rock Engineering. 35, 1(2002), pp. 45-64. DOI: $10.1007 / \mathrm{s} 006030200008$

[3] Mughieda, O.; Karasneh, I. Coalescence of offset rock joints under biaxial loading. // Geotechnical \& Geological Engineering. 24, 4(2006), pp. 985-999. DOI: 10.1007/s10706005-8352-0

[4] Lajtai, E. Z. Strength of Discontinuous Rocks in Direct Shear. // Géotechnique. 19, 2(1969), pp. 218-233. DOI: 10.1680/geot.1969.19.2.218

[5] Kwon, T. H.; Hong, E. S.; Cho, G. C. Shear behavior of rectangular-shaped asperities in rock joints. // Ksce Journal 
of Civil Engineering. 14, 3(2010), pp. 323-332. DOI: 10.1007/s12205-010-0323-1

[6] Niu, S. J.; Jing, H. W.; Hu, K.; Yang, D. Numerical investigation on the sensitivity of jointed rock mass strength to various factors. // Mining Science \& Technology. 2010, 20, 4(2010), pp. 530-534.

[7] Vergara, M. R.; Jan, M. V. S.; Lorig, L. Numerical Model for the Study of the Strength and Failure Modes of Rock Containing Non-Persistent Joints. // Rock Mechanics \& Rock Engineering. 49, (2016), pp. 1-16. DOl: 10.1007/s00603-015-0824-9

[8] Niu, Y.; Li, K. G.; Liu, D. K.; Peng, S. J. Experimental investigation on shock mechanical properties of red sandstone under preloaded 3D static stresses. // Journal of Engineering Science and Technology Review. 8, 5(2015), pp. 205-211.

[9] Chen, X.; Liao, Z. H.; Li, D. J. Experimental study of effects of joint inclination angle and connectivity rate on strength and deformation properties of rock mass under uniaxial compression. // Journal of Rock Mechanics and Engineering. 30, 4(2011), pp. 781-789.

[10] Srivastava, L. P.; Singh, M. Empirical estimation of strength of jointed rocks traversed by rock bolts based on experimental observation. // Engineering Geology. 197, (2015), pp. 103-111. DOI: 10.1016/j.enggeo.2015.08.004

[11] Liu, H. Y.; Huang, Y. S.; Li, K. B.; Zhang, J. H. Test study of strength and failure mode of pre-existing jointed rock mass. // Rock and Soil Mechanics. 34, 5(2013), pp. 12351241.

[12] Hirata, A.; Kameoka, Y.; Hirano, T. Safety Management Based on Detection of Possible Rock Bursts by $\mathrm{AE}$ Monitoring during Tunnel Excavation. // Rock Mechanics \& Rock Engineering. 40, 6(2007), pp. 563-576. DOI: 10.1007/s00603-006-0122-7

[13] Hashida, T.; Takahashi, H. Significance of AE crack monitoring in fracture toughness evaluation and non-linear rock fracture mechanics. // International Journal of Rock Mechanics \& Mining Science \& Geomechanics Abstracts. 30, 1(1993), pp. 47-60. DOI: 10.1016/0148-9062(93)90175-D

[14] Li, S. L.; Yin, X. G.; Wang, Y. J.; Fang, H. Y. Studies on acoustic emission characteristics of uniaxial compressive rock failure. // Chinese Journal of Rock Mechanics and Engineering. 23, 15(2004), pp. 2499-2503.

[15] Gao, B. B.; Li, H. G.; Yu, S. J.; Li, L. Triaxial compressed coal kind of acoustic emission and fractal feature. // Mechanics and practice. 35, 6(2013), PP. 49-54.

[16] Cundall, P. A.; Strack, O. D. L. A discrete numerical model for granular assemblies. // Géotechnique. 2015, 29, 1(2015), pp. 47-65.

[17] Itasca Consulting Group. PFC2D (particle flow code in 2 dimensions) fish in PFC2D. Minneapolis, USA, Itasca Consulting Group, 2008.

[18] Itasca Consulting Group Inc. Manual of particle flow code in 2-dimension (Version 3.10). Minneapolis, Itasca Consulting Group Inc, 2004.

[19] Zhang, X. P.; Wang, G.; Jiang, Y. J. Wang, Z. C.; Huang, N. Simulation research on granite compression test based on particle discrete element model. // Rock and Soil Mechanics. 35, supp1(2014), pp. 99-105.

[20] Park, J. W.; Song, J. J. Numerical simulation of a direct shear test on a rock joint using a bonded-particle model. International Journal of Rock Mechanics \& Mining Sciences, 46, 8(2009), pp. 1315-1328. DOl: 10.1016/j.jjmms.2009.03.007

[21] Hazzard, J. F.; Young, R. P.; Maxwell, S. C. Micromechanical modeling of cracking and failure in brittle rocks. // Journal of Geophysical Research Atmospheres. 105, B7(2000), pp. 16683-16697. DOI: 10.1029/2000JB900085

\section{Authors' addresses}

Zhi-jie Wen (corresponding author)

Research Center of Geotechnical and Structural Engineering, Shandong University, Jinan, Shandong 250061, P. R. China

College of Mining and Safety Engineering, Shandong University of Science and Technology, Qingdao 266590, P. R. China

State Key Laboratory for Geomechanics and Deep Underground Engineering, China University of Mining and Technology, Beijing 100083, China

E-mail: sdust0532@gmail.com

\section{Xiao Wang}

College of Mining and Safety Engineering, Shandong University of Science and Technology, Qingdao 266590, P. R. China

E-mail: wangchxizo@163.com

\section{Qing-hai Li}

College of Mining and Safety Engineering, Shandong University of Science and Technology, Qingdao 266590, P. R. China

E-mail: li-qinghai@163.com

Guan Lin

Department of Civil and Environmental Engineering, The Hong Kong Polytechnic University, Hong Kong, P. R. China E-mail: guanlin@polyu.edu.hk

Shao-jie Chen (corresponding author)

College of Mining and Safety Engineering, Shandong University of Science and Technology, Qingdao 266590, P. R. China

E-mail: chensj@sdust.edu.cn

Yu-jing Jiang

Faculty of Engineering, Nagasaki University,

Nagasaki 852-8521, Japan

E-mail: jiangjiang@civil.nagasaki-u.ac.jp 